\title{
The Emerging U.S.- Japan Energy Alliance and Its Implications for China
}

Chen Youjun

\begin{abstract}
Since the Tohoku earthquake and Fukushima nuclear accident in March 2011, Japan's energy policy has undergone great changes, resulting in closer energy cooperation with the United States. To serve its own national interests, the United States also began to emphasize the significance of energy cooperation under the U.S.-Japan alliance. Consequently, both countries have made strategic breakthroughs in terms of energy politics, energy economics and energy security, and a U.S.-Japan energy alliance is now taking shape. The progress of U.S.-Japan energy cooperation, on one hand, will help reduce the cost of China's natural gas import and create favorable conditions for China to promote domestic reforms in the energy sector. On the other hand, it will also present new challenges to China's geopolitical environment and its global role. While the United States continues to increase its export of liquefied natural gas (LNG) to Asian markets, China should make full use of the opportunity to speed up the development of its own shale gas resources, optimize its energy consumption structure, promote domestic energy reforms, and diversify its energy import sources. In the meantime, it should try to
\end{abstract}

Chen Youjun is Senior Fellow at the Institute of World Economy, Shanghai Institutes for International Studies (SIIS), 195-15 Tianlin Road, Shanghai 200233, China. He can also be reached at youjun21@163.com.

(c) 2017 World Century Publishing Corporation and Shanghai Institutes for International Studies China Quarterly of International Strategic Studies, Vol. 3, No. 1, 121-136

DOI: $10.1142 / S 2377740017500038$ 
work with the United States and Japan to foster an all-inclusive, long-term mechanism for energy cooperation among all countries in the Asia-Pacific.

Keywords: U.S.-Japan alliance; energy cooperation; liquefied natural gas (LNG); geopolitical competition; China's energy security.

Since the Tohoku earthquake and Fukushima nuclear accident in March 2011, Japan has enhanced its energy diplomacy toward the United States, the largest potential source of liquefied natural gas (LNG) thanks to its shale gas revolution. Out of consideration of its own economic and strategic interests, the United States has also actively responded to Japan's urgent call for more stable energy sources. Closer U.S.-Japan energy cooperation, in the context of growing strategic competition between China and the United States in recent years, is likely to exert much influence on the energy landscape of Asia-Pacific economies and, consequently, on the strategic dynamics among major powers in the region. This article examines the key driving forces behind, as well as major progress of, the energy cooperation between the United States and Japan, and discusses the implications of a potential U.S.-Japan energy alliance for China's energy security and its geopolitical environment at large.

\section{Emerging U.S.-Japan Energy Alliance After Fukushima}

The Fukushima nuclear disaster following the Tohoku earthquake and tsunami on March 11, 2011 profoundly changed Japan's long-term energy strategy that had been centered on nuclear energy for power supply. Faced with enduring public outcry, the Japanese government suspended the operation of all nuclear power plants (only three reactors have resumed in commercial operation by the time of writing of this article). At the same time, Japan had to increase its import of oil, natural gas, and other fossil fuels to guarantee domestic power supply. Against this backdrop, the prospects of the U.S.' shale gas revolution brought new hope to Japan.

In fact, the United States has been exporting Alaskan natural gas to Japan since 1973, but the export volume had been quite limited due to the strict environmental standards for energy export to Japan and other countries that have not yet signed free trade agreements (FTAs) with the 
United States. With the dawning of the U.S. shale gas revolution, President Obama and then Japanese Prime Minister Hatoyama reached an agreement on clean energy technologies in November 2009, and in November of the following year, President Obama and then Japanese Prime Minister Naoto Kan launched the Energy Smart Community Initiative and the U.S.-Japan Clean Energy Dialogue. Akihiro Ohata, then Japanese Minister of Economy, Trade and Industry, and then U.S. Secretary of Energy Steven Chu also held talks and clarified some details in these two initiatives.

Undoubtedly, Japan was extremely happy to see a booming shale industry in the United States and the U.S.' positive stance on natural gas export, both of which would provide opportunities for Japan to reduce its dependence on Middle Eastern oil. ${ }^{1}$ An increasing number of proposals were made to the Japanese government for Japan to take advantage of the U.S. shale gas revolution to adjust its energy strategy. ${ }^{2}$ Japanese Prime Minister Shinzo Abe made significant efforts to lobby U.S. politicians for approval of LNG exports to Japan. To coordinate with the government's energy diplomacy, major Japanese consortia and gas companies also flocked into natural gas development and export programs in the United States. For example, the Cove Point LNG project in Maryland was jointly developed by Sumitomo and Tokyo Gas Co., Ltd., with a maximum annual export capacity of 5 million tons; the initial export scale of the Freeport Project in Texas, where Osaka Gas Co. and Chubu Electric Power Co. hold the most stakes, was 4.4 million tons, and its maximum export capacity reaches 13 million tons per year; the Cameron Project, jointly invested by Mitsubishi Corporation and Mitsui \& Co., has a maximum annual export capacity of 12 million tons, among others. ${ }^{3}$

In response, the U.S. government showed great interest in coordinating with Japan on methane hydrate development. In May 2012, a technological test was successfully carried out in the north slope of Alaska that

${ }^{1}$ Hidehiro Muramatsu, “米国のシェール開発・生産をめぐる動向 [Trends on the Development and Production of Shale Gas in the United States]," Review on the Petroleum and Natural Gas, Issue 48, No. 1, JOGMEC, January 2014, p. 29.

${ }^{2}$ For example, see Tetsuo Yuhara, “大震災がもたらしたエネルギ一危機とその克服のため のエネルギー戦略 [Energy Crisis Caused by the Earthquake and the Energy Strategy for Overcoming That Crisis]," March 22, 2013, http://www.canon-igs.org/column/energy/ 20130322_1780.html.

${ }^{3} \mathrm{Yu}$ Mubao, “美国页岩气成日本天然气供应新选择 [U.S. Shale Gas Becomes New Choice for Japan's Natural Gas Supply]," Sinopec Monthly, July 2013. p. 100. 
would enable the safe extraction of natural gas from methane hydrates. ${ }^{4}$ Shortly afterwards, the Center for Strategic \& International Studies (CSIS) Japan Chair issued a report on the U.S.-Japan alliance, known as the Armitage-Nye Report, recommending that

[a]t a time of crisis, the United States should provide its ally with a constant and stable flow of LNG. Congress should amend the law to remove the FTA requirement for an automatic energy permit, putting Japan on an equal footing with other potential natural gas customers...[It] should better integrate and invigorate the Sciences and Technology Forum with the policy-centered Security Consultative Committee structure to further promote joint research and development and technology cooperation... ${ }^{5}$

Other private organizations also joined in such advocacy. For instance, the Japan-U.S. Business Council and its U.S. counterpart raised a proposal to the U.S. government and the Congress, suggesting expedition of new shale gas reserve exploration and execution of necessary policies to promote U.S. energy production based on market rules. ${ }^{6}$

Based on overwhelming bipartisan consensus on strengthening the U.S.-Japan alliance, in which energy cooperation is expected to play a bigger role, the U.S. government took active measures to strengthen energy ties with Japan. In July 2013, both governments reconfirmed their cooperation on the exploitation of methane hydrate, energy security, civil nuclear energy utilization, and research and

The shale gas revolution fueled both the U.S.' and Japanese expectations for closer bilateral energy cooperation.

4“U.S., Japan Successfully Test Methane Hydrate Technologies,” May 3, 2012, http:// iipdigital.usembassy.gov/st/english/article/2012/05/201205034999.html\#axzz2qzgnvVcV.

${ }^{5}$ Richard L. Armitage and Joseph S. Nye, “The U.S.-Japan Alliance: Anchoring Stability in Asia," CSIS report, August 2012, http://csis.org/files/publication/120810_Armitage USJapanAlliance_Web.pdf, p. 18.

${ }^{6}$ The U.S.-Japan Business Council and Japan-U.S. Business Council, “Joint Statement: 50th US-Japan Business Conference," November 15, 2013, http://www.jubc.gr.jp/eng/active/ pdf $/ 50 \% 20 J S \% 20$ E.pdf. 
development (R\&D) of clean energy technology. ${ }^{7}$ The U.S. Department of Energy approved several requests from the Japanese government to purchase LNG on such terms as exclusive to countries that had signed FTAs with the United States. And in October 2013, Ernest Moniz, then U.S. Secretary of Energy, confirmed that U.S. regulators were processing Japanese requests for more LNG export in a timely fashion and expected LNG exports to be flowing to Japan in "a few years." ${ }^{8}$ In a sense, the United States and Japan were on their way to becoming "natural resource allies as well as military allies." ${ }^{\prime 9}$

Ensuring safe and stable energy supply - especially the safe utilization of nuclear power - has long been the top concern for U.S.-Japan energy cooperation, and the Fukushima nuclear disaster did not halt the bilateral exchanges on civil nuclear technology. Both countries have been working hard together to complete the cleanup of the disabled Fukushima Dai-ichi Nuclear Power Plant. In March 2012, the two countries discussed the establishment of cooperation mechanisms on such topics as nuclear security, nuclear regulations, reactions to nuclear accidents, treatment of radioactive wastes and abolished nuclear facilities, high-tech nuclear power facilities, and the recycling of nuclear fuels. In April 2012, both countries decided to set up a high-level dialogue to promote their nuclear cooperation. In July that year, the U.S. Deputy Secretary of Energy and Japanese Deputy Minister for Foreign Affairs announced the establishment of a U.S.-Japan Bilateral Commission on Civil Nuclear Cooperation. This Commission included five working groups, focusing respectively on: civil nuclear energy research and development, decommissioning of the TEPCO Fukushima Dai-ichi Nuclear Power Station and environmental management, emergency management, nuclear security, as well as safety and

${ }^{7}$ Office of International Affairs of the United States, "Joint Statement between U.S. Department of Energy and Japan's Ministry of Economy, Trade and Industry," U.S. Department of Energy, July 24, 2013, http://energy.gov/node/712681.

${ }^{8}$ Meghan Gordon, “US Energy Chief Sees LNG Exports Flowing to Japan in 'Few Years,"' S\&P Global Platts, October 31, 2013, http://www.platts.com/latest-news/natural-gas/ tokyo/us-energy-chief-sees-lng-exports-flowing-to-japan-27582533.

${ }^{9}$ Richard L. Armitage and Joseph S. Nye, “The U.S.-Japan Alliance: Anchoring Stability in Asia," p. 4. 
regulatory issues. ${ }^{10}$ Thus, information exchange and technical cooperation between both countries have been institutionalized and normalized, which has been widely hailed for its raising of nuclear safety standards and strengthening of energy security for Japan.

The United States and Japan have also made efforts to promote their cooperation on multilateral and regional energy issues. Apart from such official mechanisms as the U.S.-Japan Clean Energy Policy Dialogue and the U.S.-Japan Bilateral Commission on Civil Nuclear Cooperation, both countries have set up some channels of communication, e.g., the U.S.-Japan Renewable Energy Policy Business Roundtable, that involve the private sector. In addition, both countries rely heavily on multilateral and global platforms to enhance their bilateral energy cooperation in terms of agenda setting, institutional reforms, mechanism maintenance as well as consensus building. On different regional and international forums like the International Energy Agency (IAEA), the Asia-Pacific Economic Cooperation (APEC), the Clean Energy Ministerial (CEM), the International Energy Forum (IEF), and the East Asian Summit (EAS), energy cooperation between the United States and Japan has been strengthening, leading to an emerging "energy alliance" based on shared energy interests. During the Trans-Pacific Partnership (TPP) negotiation, the United States and Japan made it clear that they should try to build a unified system of energy security cooperation in Asia led by the U.S.-Japan security alliance and based on the platform of APEC. Despite the uncertain prospects of the TPP (or its variant) under the Trump administration, the U.S.-Japan energy alliance is bound to advance further in the years to come.

\section{What Spurs U.S.-Japan Energy Cooperation?}

The upgrade of U.S-Japan energy cooperation is driven by both economic and strategic concerns of the two countries. The benefits of such cooperation to Japan are obvious. In the first place, it will greatly enhance Japan's energy security, for the country's growing dependence on the import of fossil fuels has led to an accelerating outflow of national wealth and weakened economic fundamentals, which pose serious threats to the

${ }^{10}$ Japan Ministry of Economy, Trade and Industry, FY 2013 Annual Energy Report, June 2013, p. 259. 
success of "Abenomics," Prime Minister Abe's flagship scheme to revitalize Japan's economy. ${ }^{11}$ U.S. LNG export can not only help alleviate Japan's dependence on oil and natural gas import from the Middle East, but also help Japan reduce overall energy costs and achieve structural balance of energy prices.

As of 2013, 83 percent of Japan's imported crude oil and 30 percent of imported LNG were from the Middle East. ${ }^{12}$ Any turbulence in the Middle East may interrupt Japan's energy supply. The U.S. shale gas revolution thus provides an opportunity for Japan to diversify its import sources. Diversified import sources also imply reduced transportation risks. It is notable that Japan's domestic right-wing forces constantly hype the issue of freedom of navigation in the South China Sea and the Strait of Malacca. Through conservative assertions like the "China threat" theory, Japan's right-wing forces continue to exaggerate the Philippines' and Vietnam's frictions with China over the South China Sea issue and their negative effect on the safety of South China Sea shipping lanes. It is in this context that the Japanese government has managed to rally much domestic support for importing LNG from the United States.

In terms of energy price, U.S. LNG is based on the Henry Hub Spot Price, which is about US\$3-4/mmBTU (million British Thermal Units). Even when processing and transportation costs are added, the export price of U.S. LNG to Japan is expected to be just around \$9-10/mmBTU, much lower than that in the Asian market (\$16-18/mmBTU).$^{13}$ Thus, it may stimulate the reform of regional energy pricing mechanisms for more balanced energy prices.

Second, closer U.S.-Japan energy cooperation will help Japan improve its energy import structure. Japan's total import in 2013 reached US $\$ 838.9$ billion, of which the import of mineral fuel was as high as $\$ 283.8$ billion, taking up 33.83 percent. The majority of imported mineral fuel was fossil energy like crude oil and natural gas, totaling $\$ 147.223$ billion and $\$ 73.024$ billion respectively. ${ }^{14}$ In other words, crude oil was Japan's primary

${ }^{11}$ Japan Ministry of Economy, Trade and Industry, The Fundamental Energy Strategy, April 2014, p. 8., http://www.enecho.meti.go.jp/topics/kihonkeikaku/140411_energy.pdf.

12Japan Ministry of Economy, Trade and Industry, The Fundamental Energy Strategy, p. 9.

${ }^{13}$ Ibid.

${ }^{14}$ Official website of the Japan External Trade Organization (JETRO), http://www.jetro. go.jp/world/japan/stats/trade/. 
imported energy commodity, and its import volume was twice that of natural gas. Thanks to its technological innovations and proactive energy diplomacy in recent years, Japan has gradually reduced the absolute proportion of crude oil in its overall energy import and achieved a better balance between the use of oil and natural gas. LNG imports from the United States would further help Japan to optimize its energy import structure.

Third, importing U.S. LNG motivates Japanese enterprises to invest in - and benefit from - U.S. shale gas development projects. For instance, in its new midterm plan released in 2014, Osaka Gas increased its overseas investment from 180 billion yen to 360 billion, much of which would be put into U.S. natural gas projects. ${ }^{15}$ Other Japanese financial giants including Japex, Sumitomo Corporation, Marubeni, Itochu, Mitsui, and JGC Corporation have also taken part in different U.S. natural gas projects. The stakes held by some of these Japanese giants are as high as 50 percent. ${ }^{16}$ Such investment not only improves Japan's foreign direct investment (FDI) structure in the United States, but also integrates Japanese capital more deeply into the U.S.' long-term economic development.

Finally, Japan can enhance its security alliance with the United States through closer energy cooperation, so as to strengthen its political power in global arenas. Fostering an energy alliance with the United States not only adds a new dimension to the U.S.-Japan security alliance, which used to be centered on military cooperation, but it also helps Japan extend its technological, economic and, more importantly, political influence over the global energy market with the "springboard" of the United States, thus enhancing Japan's political role on the world stage. Therefore, expanding energy cooperation with the United States and seeking U.S. exports of LNG

${ }^{15}$ OSAKA Gas Group, “大阪ガスグループ 新中期計画 (2014-2016): Catalyze Our Dreams [The New Medium-Term Plan (2014-2016): Catalyze Our Dreams]," March 13, 2014, pp. 7-8.

${ }^{16}$ Akiraho ISOKAWA, “シェールガス・オイルの現状と展望: 我が国に与え る影響に関する考察 [The Present Situation and Prospects of Oil and Shale Gas: A Study on the Influence of Our Country]," Mizuho Industry Focus, No. 117, December 13, 2012, p. 7. 
have become Japan's top priority, which may lead to a series of structural adjustments to the country's energy policy.

\section{Closer energy}

cooperation helps

strengthen the

U.S.-Japan security

alliance.

From the U.S. perspective, Japan is first and foremost a huge potential market for its soaring shale gas exploitation. According to the U.S. Energy Information Administration (EIA), U.S. natural gas production reached 10.3 trillion cubic feet in $2013,{ }^{17}$ and would increase by 113 percent for the following three decades with an annual growth rate of roughly 1 percent. $^{18}$ Besides, the EIA predicted in 2013 that the United States would have become a natural gas exporting country by $2020,{ }^{19}$ a target that has already been reached in few years. Clearly, the shale gas revolution is transforming the structure of U.S. natural gas trade with increasing possibilities of exporting LNG to Japan.

Strategically speaking, exporting LNG can enhance U.S. political and economic interests as well. U.S. politicians share a basic consensus on energy production and export. According to the above-mentioned ArmitageNye Report, Japan's LNG import from Alaska since 1969 is far from enough given its urgent need in the wake of the 2011 earthquake, and thus Washington should lift export restrictions on Japan so as to foster a "natural resource alliance" with Japan in order to consolidate the U.S.-Japan security alliance. ${ }^{20}$ On October 10, 2013, the House Subcommittee on Energy and Power held a forum on "The Geopolitical Implications and Mutual Benefits of U.S. LNG Exports." Diplomats and energy experts from 10 countries including Japan and South Korea were invited to talk with a bipartisan group on the U.S. side. Representatives from different countries all urged

${ }^{17}$ U.S. Energy Information Administration, “U.S. Natural Gas Gross Withdrawals from Shale Gas," December 30, 2016, http://www.eia.gov/dnav/ng/hist/ngm_epg0_fgs_nus_ mmcfA.htm.

${ }^{18}$ U.S. Energy Information Administration, Annual Energy Outlook 2013 (Washington, D. C.: U.S. Energy Information Administration, April 2013), p. 79, http://www.eia.gov/ outlooks/aeo/pdf/0383(2013).pdf.

${ }^{19}$ Ibid., pp. $78-79$.

${ }^{20}$ Armitage and Nye, “The U.S.-Japan Alliance: Anchoring Stability in Asia,” pp. 3-4. 
the United States to examine and approve LNG export projects as soon as possible, and pragmatically undertake its leadership in global energy diplomacy. Subcommittee chairman Whitfield gave a rather positive response to the audience. ${ }^{21}$ To follow up, on March 16, 2014, the Subcommittee held a hearing on the "Benefits of and Challenges to Energy Access in the 21st Century: Fuel Supply and Infrastructure," on which Mr. Whitfield's opening statement reflected Washington's strong interest in developing domestic energy infrastructure and expanding energy export. ${ }^{22}$

\section{Recent Progress of U.S.-Japan Energy Cooperation}

Based on shared interests and demands, the United States and Japan have been quite active in promoting their energy cooperation, which can be seen in many new breakthroughs in terms of energy politics, energy economics, and energy security. It is fair to say that U.S.-Japan energy cooperation has increasingly developed into comprehensive, institutionalized strategic cooperation between both countries.

Above all, the United States and Japan have enhanced their coordination on energy policies to achieve the U.S.-led security agenda. Take their actions on the Ukraine Crisis, for example: the Abe administration quickly joined in U.S. sanctions against Russia and took rather slow steps to ameliorate Russia-Japan political relations afterwards, in spite of the high possibilities of reduction or even interruption of Russian energy supply to Japan. In other words, even when faced by immediate energy security risks, Japan still chose to follow the lead of the U.S., though in a more subdued manner.

Also, the two countries have deepened their integration on energy economics and decided on the direction to further develop their bilateral energy cooperation based on innovation projects. As mentioned above,

21 “Members and Foreign Diplomats Discuss Mutual Benefits of U.S. LNG Exports," Energy and Commerce Committee, October 10, 2013, http://energycommerce.house.gov/ event/geopolitical-implications-and-mutual-benefits-us-lng-exports.

${ }^{22}$ See Ed Whitfield's opening statement at the hearing on the "Benefits of and Challenges to Energy Access in the 21st Century: Fuel Supply and Infrastructure," Subcommittee on Energy and Power, House Energy and Commerce Committee, Washington, D.C., March 6, 2014, http://energycommerce.house.gov/sites/republicans.energycommerce.house.gov/ files/Hearings/EP/20140306/HHRG-113-IF03-MState-W000413-20140306.pdf. 
an increasing number of Japanese companies have participated in the exploration and exploitation of U.S. shale gas. Meanwhile, the United States continues to support Japan's claim on resource ownership in disputed "territorial waters" by political and military means. Besides, the United States and Japan have been jointly exploiting the latter's offshore methane hydrate. In the eastern Nankai Trough off Japan's Pacific coast, reserves of methane hydrates are estimated to be 1.1 trillion cubic meters, which can ensure 11 years of consumption. Since 2001, Japan has invested hundreds of millions of dollars in research and development with respect to extracting natural gas from methane hydrates. ${ }^{23}$ On March 12, 2013, Japan Oil, Gas and Metals National Corporation announced that it had extracted gas from offshore methane hydrates for the first time in the world. ${ }^{24}$ With the development of U.S. shale gas and Japan's methane hydrates, both countries are enhancing policy coordination as well as technological and financial cooperation in the energy sector.

The U.S. and Japan are working together to develop natural gas resources and dominate sea routes for LNG transportation.

Furthermore, the two countries are undertaking joint efforts to enhance "free and safe transportation" by monopolizing vehicles and waterways. In terms of transportation vehicles, LNG tankers are of high added values with many technological barriers. So far, only a small number of manufacturers in the United States, Japan, South Korea, and a few European countries are able to build LNG tankers. U.S.-Japan cooperation on building LNG tankers is being promoted in a swift way. For instance, Mitsui Engineering \& Shipbuilding, together with other Japanese ship manufacturers, conducted a joint bidding to build LNG tankers for U.S. LNG export projects. Several Japanese shipping companies, including Mitsui O.S.K. Lines, plan to order 90 brand-new LNG tankers by 2020 with an estimated cost of $\$ 17.6$ billion, for the purpose of importing

${ }^{23}$ Osamu Tsukimori, "Japan Achieves First Gas Extraction from Offshore Methane Hydrate," Reuters, March 12, 2013, http://www.reuters.com/article/2013/03/12/us-methanehydrates-japan-idUSBRE92B07620130312.

${ }^{24}$ Ibid. 
LNG from North America and Australia. ${ }^{25}$ The devaluation of the yen due to Abenomics has further bolstered the market value of Japanese shipping companies in the sea-lane LNG transportation business.

In addition, the United States has actively sought to widen the Panama Canal, so as to shorten its maritime distance from Japan. This project would provide a shortcut for U.S. natural gas export to Asian countries like Japan, South Korea and China, and facilitate U.S. manufacturers' participation in natural gas market competition in Asia. According to IHS, a globally leading consulting company, the new Panama Canal would greatly shorten the LNG transportation distance from the United States to Japan, and export costs would be reduced by $\$ 1.50$ per mmBTU. Other costs included, there would still be approximately a $\$ 1.2$ price margin per mmBTU for U.S. LNG. ${ }^{26}$

\section{Implications of the U.S.-Japan Energy Alliance for China}

Evidently, strengthened U.S.-Japan energy cooperation will exert significant impact on the global energy landscape. As the world's biggest energy consumer, China will be faced with both opportunities and challenges from a potential U.S.-Japan energy alliance.

On one hand, the ever closer U.S.-Japan energy cooperation is likely to shape a new natural gas pricing mechanism that involves China, the United States, Japan, and other stakeholders in the Asian market. In recent years, China's energy imports have been skyrocketing in parallel with the rapid growth in demand. The Chinese government has long been aware of its dependence on energy imports, and it has been working hard to diversify sources of oil and natural gas through a combination of domestic production and imports. If U.S. natural gas production keeps rising, the U.S. government may very likely adopt a new policy to encourage LNG export, even to those countries that have not signed FTAs with the United States.

${ }^{25}$ Yuka Obayashi and Keith Wallis, “Japan Shippers Plan to Order 90 New LNG Tankers Worth \$17.6 Billion by 2020," Reuters, November 29, 2013, http://www.reuters.com/ article/2013/11/29/us-japan-shippers-plan-idUSBRE9AS05V20131129.

${ }^{26}$ Andrew Callus and Oleg Vukmanovic, “U.S. Gas via Panama Frightens LNG Exporters Worldwide," Reuters, September 5, 2013, http://www.reuters.com/article/energylng-world-idUSL6N0GV37820130905. 
Consequently, Asian countries including China would benefit from this new source of energy supplies at more favorable prices, which will also reduce the cost of China's domestic use of natural gas and, as a result, promote China's reform of its own gas pricing mechanism. It will thus be less difficult for China to meet the greenhouse gas emission targets and fulfill its commitment on combating climate change.

On the other hand, the upgrade of U.S.-Japan energy cooperation will bring new challenges to China's geopolitical environment and its global role. According to a report published by the National Intelligence Council (NIC) in December 2012, the U.S. shale gas revolution would generate significant effect on international relations and geopolitics. ${ }^{27}$ One possible scenario is that as the United States becomes energy independent thanks to the shale gas revolution, it may start a phased withdrawal from the Middle East. Although it will not completely abandon its role in Middle Eastern affairs due to the necessity of maintaining stability in international crude oil prices and for security concerns of its closest ally, Israel, its foreign policy focus will surely shift to Asia.

With this new international energy dynamics, China will feel mounting strategic pressures from the United States to shoulder greater security and diplomatic responsibilities both in the Middle East and the Asia-Pacific. Since Middle Eastern countries are still China's key sources of oil and natural gas import, China has to invest more resources in safeguarding energy supply and transportation routes from the Middle East and play a proactive role in regional affairs. In the Asia-Pacific, the maritime transportation routes are largely under the U.S. military dominance. In recent years, the United States has been exploring the possibility of inviting allies, such as Japan and South Korea, to participate in the so-called "freedom of navigation (FON)" missions in the region. From the U.S. perspective, it has spent an enormous amount of money in maintaining the safety of global maritime shipping routes, while China has long enjoyed this benefit and is virtually a free-rider; it is thus likely to put pressure on China to accept maritime responsibilities by itself and pay its way.

${ }^{27}$ National Intelligence Council, Global Trends 2030: Alternative Worlds (Washington, D.C.: Office of the Director of National Intelligence, December 2012), https://www.dni. gov/files/documents/GlobalTrends_2030.pdf. 
The U.S.-Japan energy alliance will further strengthen their political and military ties and create more space for Japan to support the U.S. rebalancing (possibly taking on another name under the Trump administration) to Asia, and put China into an unfavorable position. To be more specific, the United States has started to increase LNG export to Japan and South Korea so as to reduce their dependence on energy imports from the Middle East, which would in turn consolidate the U.S.' geopolitical status in the Asia-Pacific vis-à-vis China.

The U.S.-Japan energy alliance may also speed up Japan's exploitation of methane hydrate resources in disputed waters with China, causing more tensions between both countries. The exploitation of oil and natural gas resources in the East China Sea and sovereignty of the Diaoyu Islands have long been the focal points of territorial disputes between China and Japan. Japan's claim to the sovereignty of the Diaoyu Islands is, to a large extent, driven by its motivation to exploit seabed resources. For that is the fastest way for resource-poor Japan to reduce its overreliance on external supplies. To contain China's rapid rise in Asia, the United States would rather maintain the status quo of China-Japan territorial disputes and even implicitly support Japan's claim through strategic reassurance. As military allies, Washington and Tokyo keep a watchful eye on the "threat" from a strengthening Chinese navy and try to confine China to the so-called "first and second island chains," which would pose lasting barriers to the Chinese ambition to become a great power with a bigger regional and global role to play.

By exporting natural gas to Japan and some other Asia-Pacific countries, the United States will be able to further improve its relations with those countries in the energy sector, and thus acquire a stronger voice in pushing forward bilateral or multilateral trade negotiations like the seemingly abandoned Trans-

The U.S.-Japan energy alliance puts increasing strategic pressure on China. Pacific Partnership (TPP) that are set to counteract China's growing regional economic influence. In short, the United States seeks to establish a new political and economic advantage in the Asia-Pacific via LNG export.

So far, the Chinese government has not expressed direct concerns over this strengthening of U.S.-Japan energy cooperation. Nor is it likely to do so 
in the future as long as that does not cause conspicuous negative impact on regional and global energy markets. Instead, China is hopeful that closer U.S.-Japan energy cooperation, if it is open to other countries as both governments have reiterated, may contribute to the stability of energy prices in Asian and global markets. Therefore, despite increasing strategic pressure from the emerging U.S.-Japan energy alliance, China can indeed choose to work with the United States and Japan to construct a trilateral framework for energy cooperation, in order to promote the long-term energy cooperation among all countries in the Asia-Pacific.

\section{Conclusion}

Since the Tohoku earthquake and Fukushima nuclear accident in March 2011, Japan's energy policy has undergone great changes, characterized by ever-closer energy cooperation with the United States. Based on its own economic and national strategic demands, the United States has also begun to highlight the role of energy cooperation in the U.S.-Japan security alliance. As a result, Washington and Tokyo have made many breakthroughs in various fields, including energy politics, energy economics, and energy security, and a U.S.-Japan energy alliance seemed to be taking root. The upgrade of U.S.-Japan energy cooperation, on one hand, will be conductive to reducing the cost of China's natural gas import and creating favorable conditions for China to promote domestic reforms of the energy sector. Yet on the other hand, it will present many challenges to China's energy security and its geopolitical environment.

In this light, China needs to keep a close watch on the development of U.S.-Japan energy cooperation and fully apprehend the strategic intentions behind U.S. LNG exports. To optimize its energy structure and promote domestic energy reforms, China should make full use of the opportunity of the U.S.' increasing LNG export to the Asian market; in the meantime, it needs to continue with the diversification of its energy import sources by enhancing energy cooperation with Russia and Central Asian states in addition to Middle Eastern countries. Moreover, since China holds abundant untapped shale gas reserves, it must quicken its steps in the exploration and production of shale gas as a stable source of energy supply.

Ultimately, the actual effect of future U.S.-Japan energy cooperation depends on the strategic goals of such cooperation. If it is aimed at 
restricting China's energy import sources and dominating sea routes used for China's energy transportation, then it will not only lead to strong counteractions from China, but constrain the economic interests of the United States and Japan as well. However, if such cooperation is meant to be inclusive and mostly business-driven, then it is possible to engage China and other Asia-Pacific countries gradually to construct a new regional and even global framework for securing energy supplies and stabilizing energy prices, which would be a great contribution to more sustainable and balanced development of the global economy. 